magnitude of need becomes more apparent. On the other end of the scale is Germany's ever-growing need for more workers for their busy factories. These come primarily from the underdeveloped southern countries and are referred to as "guest workers". Only the men are usually in evidence and the title defines their temporary status. It is interesting to note that a new type of discrimination is appearing and we have seen several big billboards proclaiming "The guest worker is thy neighbour too".

This economic resurgence has also changed the German's attitude towards emigration. Although young girls are willing to take jobs as domestics or nurses (only jobs that are usually open to them) in England or North America, most are interested in learning the language rather than making a permanent commitment. And while many ambitious Germans skilled (including professionals) and unskilled could see only a limited future in their own country a few years ago and have dispersed widely over the world, we have met several that have now returned to resume their life in Germany.

Students from the following countries participated in the course. If any Canadian forester has occasion to visit these countries, the authors will be glad to provide the names and interests of course participants on request.

Argentina, Australia, Austria, Brazil, Bulgaria, Canada, Czechoslovakia, Finland, West Germany, Hungary, Israel, Italy, Japan, New Zealand, Pakistan, Philippines, Poland, South Vietnam, Sweden, Syria, Thailand, United States of America.

\title{
1967 IUFRO MEETING
}

In agreement with the President of IUFRO, Professor Dr. Dr.h.c. J. Speer, the German Union of Forestry Research Organizations (President, Professor K. Mantel) takes pleasure in giving notice that the next IUFRO Congress will be held in Munich from 4-9 September, 1967.

There will be prepared major excursions covering the entire territory of the Federal Republic in addition to various excursions being arranged for certain geographic areas and special fields of forestry.

The IUFRO Congress Bureau has been set up in Munich 13, Amalienstrasse 52/11, West Germany.

\section{Background to Adoption of ONTARIo Log Rule}

Lettens from Professor F. M. Buckingham, Faculty of Forestry, University of Toronto, and Mr. C. R. Mills, formerly Secretary-Manager, Ontario Forest Industries Association and Member, Joint Industry Scaling Committee, take exception to the following statement in my article "The Measurement of Forest Products in Canada: Past, Present and Future. Historical and Legislative Background", published in the March issue of the Forestry Chronicle:

"Despite industry opposition to the proposed change, the Ontario Log Rule was developed by the Minister, February 15, 1952."

The words "despite industry opposition" are deemed to be too strong and my correspondents suggest that they "convey to the uninformed the convicition that the forest industry in Ontario was unalterably opposed to the introduction of the Ontario Log Rule. Such I am assured "was definiely not the case".

This matter would have been placed in better perspective had I quoted the 
following statement by Morison and Pennock (1952) in "The Ontario Log Rule":

"Objections to a change were made but, as there was determination to proceed and study the problem, meetings were arranged by the Minister between the Government and representatives of industry on January 14th, and 29th, 1952, which finally resulted in the unanimous approval of the formation of the Ontario Log Rule . . . The department then proceeded to calculate all the values for the rule, which received the approval of the Minister on February 1.5th, 1952."

J. W. KER

\section{ANDRE LiNTEAU}

Un ingénieur forestier bien connu le Dr. André Linteau est décedé subitement le lundi 21 février 1966. Il était âgé de 55 ans.

Gradué de la Faculté de foresterie et de géodésie de l'Université Laval en 1935, il obtint de l'Université Yale une maîtrise en foresterie (M.F.) en 1940 et un doctorat en philosophie (Ph.D.) en 1946. Jusqu'en 1949 il fut à l'emploi du gouvernement du Québec.

En 1949 il joignit le ministère du Nord Canadien et des Ressources Nationales où il s'occupa de recherches forestières plus spécialement en écologie et en sylviculture. A son décès il était directeur adjoint au ministère des Forêts du Canada pour la région du Québec. Il avait été nommé à ce poste au printemps de 1965 . Le Dr. Linteau a publié une liste imposante de brochures et feuillets scientifiques. Il fut l'un des pionniers pour ce qui est de la classification des forêts à partir de donnés phytosociologiques (végétation forestière).

Il fut président de la Corporation des ingénieurs forestiers du Québec en 1960; il était membre de l'Institut forestier du Canada, de l'Institut professional du Service public du Canada, de la Société d'Ecologie de l'Amérique et de l'Association Forestière Québecoise. Il était également professeur titulaire à la Faculté de foresterie et de géodésie de l'Université Laval.

MiCHEL JURDENT 